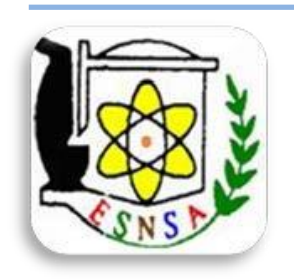

Arab Journal of Nuclear Sciences and Applications

ISSN 1110-0451

Web site: ainsa.journals.ekb.eg

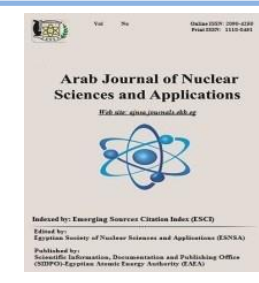

(ESNSA)

\title{
Effect of Boron and Nitrogen on Growth and Yield of Onion (Allium cepa L.) Plant Using N-15 Technique
}

\author{
El-Sherbeny T. M. S. and Hashim M. E. \\ Plant Research Department, Nuclear Research Center, Atomic Energy Authority, Egypt
}

Received $20^{\text {th }}$ Jan. 2020 Boron nutrient plays an important role for crop growth and production. However, the adequate amount Accepted $20^{\text {th }} \mathrm{Feb} .2020$ of nitrogen and boron that improves plant production and nitrogen use efficiency is still remaining unknown particularly under sandy soil. Thus, field experiments were conducted in two consecutive growing seasons (from 2016 to 2018) at the Experimental Farm at the Nuclear Research Center, Atomic Energy Authority, Inshas, Egypt to investigate the effects of boron foliar nutrition and nitrogen fertilizer rates on the growth, yield, and nitrogen utilized by onion plant cv. Giza 20. The experiment was laid out in randomized complete block design with six levels of boron (Control, 0.8, 1.6, 2.4, 3.2 and 4 ppm), and three rates of nitrogen $\left(40,60\right.$ and $80 \mathrm{~kg} \mathrm{~N} / \mathrm{fed}^{-1}$ as ammonium sulphate) in reclaimed sandy soil. The results showed that boron at $2.4 \mathrm{ppm}$ interacted with nitrogen rate at $80 \mathrm{~kg} \mathrm{~N} / \mathrm{fed}^{-1}$ which significantly increased fresh and dry weight g/plant, total chlorophyll content $(58.67$ and $58.00 \mathrm{mg} / \mathrm{g} \mathrm{dry}$ weight), biological yield $\left(2.53\right.$ and $\left.2.80 \mathrm{~kg} / \mathrm{m}^{2}\right)$, economical yield $\left(2.23\right.$ and $\left.2.30 \mathrm{~kg} / \mathrm{m}^{2}\right)$ and nitrogen utilized percentage $(38.25$ and $37.68 \%)$ in the two growing seasons respectively. Foliar boron application at rate of 3.2 and $4.0 \mathrm{ppm}$ with all nitrogen rates significantly decreased all the studied character. On the contrary, Potassium and boron content in the bulbs were increased as the boron application rate increased. The present data indicated that the interaction between boron at 2.4 ppm and nitrogen at 80 $\mathrm{kg} \mathrm{N} / \mathrm{fed}^{-1}$ was the best treatment for better growth and yield of onion under these reclaimed sandy soil.

Keywords: Onion, Boron, Nitrogen, Yield, N-15 Technique

\section{Introduction}

Onion (Allium cepa L.) is one of the most important commercial vegetable crops in Egypt. It belongs to the family Alliaceae. Onion is used as a main constituent in most human beings' food products and is also cooked alone as a vegetable. It contains carbohydrate, protein, thiamine, riboflavin, niacin and ascorbic acid [1]. The distinctive and pungency in onion due to a sulphurous volatile oil is known as allyl propyl disulphide. Onion contains chemicals compounds known as granosulfur that have linked to lowering blood pressure and cholesterol. Also, onion contains thiosulphinate which is effective in killing many common bacteria [2]. Therefore, it significantly contributes to the nutritional requirements of human beings and has also medicinal values.

Sandy soils are of poor nutrient nature which affects growth and productivity of vegetables including onion. Mineral fertilizers are considered to be an important source of macro and microelement in crop production.

Nitrogen is needed mainly as macro-element in greatest quantities to maximize growth and productivity of all plants and onion crop. The beneficial effect of nitrogen application on onion yield showed that the highest values for plant height and bulb diameter were obtained at rates of 180 and $240 \mathrm{~kg} \mathrm{~N} /$ ha. respectively [3].

Boron is one of the essential micronutrients required for normal plant growth and productivity.

Corresponding author: mehashim@yahoo.com

DOI: 10.21608/ajnsa.2021.30929.1354

(C) Scientific Information, Documentation and Publishing Office (SIDPO)-EAEA 
Boron is one of the essential micronutrients required for normal plant growth and productivity. Boron has several functions in plant growth. There is evidence that boron is necessary for normal cell division, cell wall formation, sugar transport, pollen germination and nitrogen metabolism [4]. Foliar application of micronutrients $(\mathrm{Zn}, \mathrm{B})$ is more effective than soil application for supplying nutrients to plant directly and quickly [5] as well as avoiding not only nutrient fixation in the soil, but also leaching during irrigation. When boron is added at one ppm to red onions grown in sand culture, it gives the best results of leaves and root numbers and when it is added at two ppm, plant height increased[6] .

Therefore, this study aims at elucidating the effect of different rates of boron foliar nutrition (control, 0.8, 1.6, 2.4, 3.2 and $4 \mathrm{ppm}$ ) and nitrogen fertilizer $\left(\left(40,60\right.\right.$ and $\left.80 \mathrm{~kg} \mathrm{~N} / \mathrm{fed}^{-1}\right)$ on the growth, yield, and nitrogen utilized by onion plant cv. Giza 20.

\section{Material and Methods \\ Growth conditions}

The experiment was conducted during the two growing seasons of (2016 - 2017) and (2017 2018) at the Experimental Farm of Nuclear Research Center, Atomic Energy Authority, Inshas, Egypt, to study the impact of boron and nitrogen fertilization on onion plant in reclaimed sandy soil using drip irrigation system (spaces between laterals were $30 \mathrm{~cm}$ and distance between dripper was $15 \mathrm{~cm}$ ). Onion (Allium cepa L.) C.v. Giza 20 seeds were planted in nursery for 60 days and then the transplants were transplanted to the sustainable field Dec. 4, 2016 and Dec. 6, 2017 growing seasons respectively. The transplants were settled up on the two sides of the irrigation line. The experimental area was divided into equal size plots; the plot area was $10.5 \mathrm{~m}^{2}(3.5 \mathrm{~m}$ long $\times 3 \mathrm{~m}$ wide).

\section{Experimental treatments}

\section{I-Boron treatments}

The treatments included 6 levels of boron (Control, 0.8, 1.6, 2.4, 3.2 and $4 \mathrm{ppm}$ ) at the form of boric acid. Onion plants were sprayed two times with boric acid at monthly starting from 30 days after transplanting. Foliar sprays were carried out in the morning using a hand pressure.

\section{II-Nitrogen treatments}

Three nitrogen fertilizer levels for onion plants
(40, 60 and $80 \mathrm{~kg} \mathrm{~N} / \mathrm{fed}^{-1}$ ) were applied in the form of ammonium sulfate (21.2\%) through three equal splitting doses started 21 days after transplanting through fertigation technique.

To study N-utilized, $\mathrm{N}-15$ labeled fertilizer doses were applied using ammonium sulphate of $5 \%$ atom excess in a micro plot $(1.5 \mathrm{~m}$ long x $0.3 \mathrm{~m}$ apart) to be $0.45 \mathrm{~m}^{2}$. Calcium superphosphate $(15.5$ $\left.\% \mathrm{P}_{2} \mathrm{O}_{5}\right)$ at rate of $300 \mathrm{Kg} / \mathrm{fed}^{-1}$ and potassium sulphate $\left(48 \% \mathrm{~K}_{2} \mathrm{O}\right)$ at the rate of $150 \mathrm{Kg} / \mathrm{fed} .^{-1}$ were applied to onion plants in a solution form through the fertigation system.

\section{Sampling and analysis}

The plant samples were collected, 90 days after transplanting to measure the following characters:

\section{A- Growth parameters}

1- Fresh and dry weight (bulb + shoot) g/plant.

2- Total chlorophyll (mg/g dry weight) in green leaves using chlorophyll meter (Minolta SPAD502, spectrum technologies Inc, plain field, 1L).

\section{B- Yield}

1- Biological yield $\left(\mathrm{kg} / \mathrm{m}^{2}\right)$ : plants weight after 15 days from harvesting.

2- Economical yield $\left(\mathrm{kg} / \mathrm{m}^{2}\right)$ : bulbs weight after 15 days from harvesting.

\section{C- Chemical characteristics}

1- Total nitrogen $(\%)$ in bulbs was determined using Kjeldahl method [7].

2- Potassium (\%) in bulbs was determined using atomic absorption Spectrometry (Shimadzu 6800).

3- Boron concentration (ppm) in bulbs was determined utilizing the azomethine dye method and measured using the UV-VIS spectrophotometer (Shimadzu 6800) at $420 \mathrm{~nm}$ [8].

D- N-utilized (\%): atom excess in plant sample was measured using the Emission Spectrometry N15 Analyzer (Model NoI - 6 PC) [9] according the following equation:

$$
\begin{aligned}
& \text { 1) } \mathrm{N} \text {-derived from fertilizer }(\% \mathrm{Ndff})= \\
& \frac{\%^{15} \mathrm{~N} \text { atom excess in plant sample }}{\%^{15} \mathrm{~N} \text { atom excess in fertilizer }} \times 100
\end{aligned}
$$

and then $\mathrm{N}$ derived from fertilizer (g/area) was measured according the following equation:

Ndff $(g /$ area $)=\%$ Ndff $\times$ total $\mathrm{N}$ uptake $(g /$ area $)$

2) $\%$ N-utilized $=\frac{\text { Ndff }(g / \text { area })}{\text { Fertilizer rate }} \times 100$ 
Statistical analysis

The experiments were designed in randomized complete block design (RCBD) in three replicates. Data obtained were analyzed statistically [10]. Using Mstat statistical program. The means difference among the treatments was compared by least significant difference (LSD) at 0.05 [11].

\section{Results and Discussion}

\section{A. Growth parameters of Onion plant}

\section{Fresh and dry weight}

Data in Tables (1 and 2) showed that the fresh and dry weight significantly increased in response to boron foliar application in both seasons of the study. The increament continued up to $2.4 \mathrm{ppm}$ boron rate followed by a reduction at higher boron rates (3.2 and $4.0 \mathrm{ppm})$. The results were in agreement with those observed by Paul et. al,( 2007) [12] who found that boron foliar application at rate of $1 \mathrm{~kg} / \mathrm{ha}$ significantly increased the fresh and dry weight of onion plants.
Nitrogen fertilization significantly affected fresh and dry weights as shown in Tables (1 and 2). The highest fresh and dry weights were obtained in case of using the highest rate of nitrogen level (80 $\mathrm{kg} \mathrm{N} / \mathrm{fed}^{-1}{ }^{-1}$.

The effect of the interaction between boron and nitrogen showed that boron at $2.4 \mathrm{ppm}$ and nitrogen at $80 \mathrm{~kg} \mathrm{~N} / \mathrm{fed} .^{-1}$ was the best treatment which gave the highest fresh and dry weights, whereas the increment in fresh weight/plant reached $46.65 \%$ and $46.70 \%$ for the two growing seasons respectively as shown in Table (1) compared to the control. Also, the increment percentage in dry weight/plant reached $29.65 \%$ and $29.57 \%$ as shown in Table (2) for the two growing seasons respectively compared to the control.

\section{Chlorophyll content}

Results in Table (3) show a significant increase in total chlorophyll content as the boron application rate increased. The increase continued

Table (1): Effect of boron and nitrogen fertilizer on fresh weight of onion (g/plant) during the two growing seasons of 2016/2017 and 2017/2018

\begin{tabular}{|c|c|c|c|c|c|c|c|c|}
\hline \multirow{3}{*}{ Boron conc. ppm } & \multicolumn{8}{|c|}{ Nitrogen rates kg N/fed. $^{-1}$} \\
\hline & \multicolumn{3}{|c|}{$2016 / 2017$} & \multirow{2}{*}{ Average } & \multicolumn{3}{|c|}{$2017 / 2018$} & \multirow{2}{*}{ Average } \\
\hline & 40 & 60 & 80 & & 40 & 60 & 80 & \\
\hline Control & 76.83 & 85.67 & 99.67 & 87.39 & 76.28 & 85.00 & 98.90 & 86.73 \\
\hline 0.8 & 79.33 & 89.33 & 105.3 & 91.33 & 78.33 & 88.63 & 104.5 & 90.50 \\
\hline 1.6 & 84.33 & 91.00 & 111.7 & 95.67 & 83.70 & 90.30 & 110.8 & 94.93 \\
\hline 2.4 & 89.33 & 97.33 & 112.7 & 99.78 & 88.67 & 96.60 & 111.9 & 99.05 \\
\hline 3.2 & 72.33 & 76.33 & 76.33 & 75.00 & 71.80 & 75.77 & 75.77 & 74.44 \\
\hline 4.0 & 71.33 & 73.33 & 74.00 & 72.89 & 70.80 & 72.77 & 73.47 & 72.34 \\
\hline Average & 78.92 & 85.50 & 96.61 & & 78.33 & 84.84 & 95.89 & \\
\hline \multicolumn{9}{|l|}{ L.S.D. at 0.05 for: } \\
\hline Nitrogen & & 1.28 & & & & 2.06 & & \\
\hline Boron & & 1.81 & & & & 2.92 & & \\
\hline Nitrogen $\times$ Boron & & 3.14 & & & & 5.06 & & \\
\hline
\end{tabular}

Table (2): Effect of boron and nitrogen fertilizer on dry weight of onion

(g/plant) during the two growing seasons of 2016/2017 and 2017/2018

\begin{tabular}{|c|c|c|c|c|c|c|c|c|}
\hline \multirow{3}{*}{ Boron conc. ppm } & \multicolumn{8}{|c|}{ Nitrogen rates kg N/fed. ${ }^{-1}$} \\
\hline & \multicolumn{3}{|c|}{$2016 / 2017$} & \multirow{2}{*}{ Average } & \multicolumn{3}{|c|}{$2017 / 2018$} & \multirow{2}{*}{ Average } \\
\hline & 40 & 60 & 80 & & 40 & 60 & 80 & \\
\hline Control & 28.33 & 30.73 & 30.87 & 29.98 & 30.23 & 32.80 & 32.93 & 31.69 \\
\hline 0.8 & 29.50 & 32.67 & 35.27 & 32.48 & 31.47 & 34.87 & 37.63 & 34.66 \\
\hline 1.6 & 30.27 & 34.00 & 36.33 & 33.53 & 32.27 & 36.27 & 38.77 & 35.77 \\
\hline 2.4 & 30.90 & 34.86 & 36.73 & 34.17 & 32.97 & 37.20 & 39.17 & 36.44 \\
\hline 3.2 & 26.33 & 25.10 & 26.30 & 25.91 & 28.07 & 26.77 & 28.07 & 27.63 \\
\hline 4.0 & 25.00 & 25.00 & 25.03 & 25.01 & 26.67 & 26.30 & 26.70 & 26.56 \\
\hline Average & 28.39 & 30.39 & 31.76 & & 30.28 & 32.37 & 33.88 & \\
\hline \multicolumn{9}{|l|}{ L.S.D. at 0.05 for: } \\
\hline Nitrogen & & 0.229 & & & & 0.873 & & \\
\hline Boron & & 0.324 & & & & 1.234 & & \\
\hline Nitrogen $\times$ Boron & & 0.560 & & & & 2.138 & & \\
\hline
\end{tabular}


Table (3): Effect of boron and nitrogen fertilizer on chlorophyll content of onion (mg/g dry weight) during the two growing seasons of 2016/2017 and 2017/2018

\begin{tabular}{|c|c|c|c|c|c|c|c|c|}
\hline \multirow{3}{*}{ Boron conc. ppm } & \multicolumn{8}{|c|}{ Nitrogen rates kg N/fed. $^{-1}$} \\
\hline & \multicolumn{3}{|c|}{$2016 / 2017$} & \multirow{2}{*}{ Average } & \multicolumn{3}{|c|}{$2017 / 2018$} & \multirow{2}{*}{ Average } \\
\hline & 40 & 60 & 80 & & 40 & 60 & 80 & \\
\hline Control & 50.00 & 54.00 & 54.67 & 52.89 & 50.33 & 53.67 & 53.67 & 52.56 \\
\hline 0.8 & 53.67 & 55.67 & 57.33 & 55.56 & 52.00 & 55.33 & 57.33 & 54.89 \\
\hline 1.6 & 55.33 & 55.67 & 58.33 & 56.44 & 55.67 & 56.00 & 57.67 & 56.44 \\
\hline 2.4 & 55.00 & 51.33 & 58.67 & 57.11 & 55.67 & 56.33 & 58.00 & 56.67 \\
\hline 3.2 & 50.33 & 51.33 & 52.00 & 51.22 & 50.33 & 50.33 & 51.00 & 50.56 \\
\hline 4.0 & 50.33 & 54.28 & 51.33 & 51.00 & 50.00 & 53.67 & 50.67 & 50.33 \\
\hline Average & 52.44 & & 55.39 & & 52.33 & & 54.72 & \\
\hline \multicolumn{9}{|l|}{ L.S.D. at 0.05 for: } \\
\hline Nitrogen & & 0.450 & & & & 0.437 & & \\
\hline Boron & & 0.637 & & & & 0.619 & & \\
\hline Nitrogen $\times$ Boron & & 1.104 & & & & 1.072 & & \\
\hline
\end{tabular}

Table (4): Effect of boron and nitrogen fertilizer on biological yield of onion $\left(\mathrm{Kg} / \mathrm{m}^{2}\right)$ during the two growing seasons of 2016/2017 and 2017/2018

\begin{tabular}{|c|c|c|c|c|c|c|c|c|}
\hline \multirow{3}{*}{ Boron conc. Ppm } & \multicolumn{8}{|c|}{ Nitrogen rates kg N/fed. ${ }^{-1}$} \\
\hline & \multicolumn{3}{|c|}{$2016 / 2017$} & \multirow{2}{*}{ Average } & \multicolumn{3}{|c|}{$2017 / 2018$} & \multirow{2}{*}{ Average } \\
\hline & 40 & 60 & 80 & & 40 & 60 & 80 & \\
\hline Control & 1.847 & 2.020 & 2.353 & 2.073 & 2.033 & 2.233 & 2.593 & 2.287 \\
\hline 0.8 & 1.920 & 2.113 & 2.393 & 2.142 & 2.120 & 2.337 & 2.643 & 2.367 \\
\hline 1.6 & 1.980 & 2.390 & 2.460 & 2.277 & 2.187 & 2.643 & 2.717 & 2.516 \\
\hline 2.4 & 2.163 & 2.430 & 2.533 & 2.376 & 2.393 & 2.683 & 2.800 & 2.626 \\
\hline 3.2 & 1.633 & 1.750 & 1.823 & 1.736 & 1.803 & 1.903 & 1.987 & 1.898 \\
\hline 4.0 & 1.610 & 1.720 & 1.757 & 1.696 & 1.780 & 1.897 & 1.950 & 1.876 \\
\hline Average & 1.859 & 2.071 & 2.220 & & 2.053 & 2.283 & 2.448 & \\
\hline \multicolumn{9}{|l|}{ L.S.D. at 0.05 for: } \\
\hline Nitrogen & & 0.037 & & & & 0.021 & & \\
\hline Boron & & 0.052 & & & & 0.030 & & \\
\hline Nitrogen $\times$ Boron & & 0.091 & & & & 0.052 & & \\
\hline
\end{tabular}

up to the $2.4 \mathrm{ppm}$ boron rate during the two growing seasons of this study, the highest level of nitrogen fertilizer significantly increased the total chlorophyll content in onion plant leaves as well

Also, the effect of the interaction between boron at $2.4 \mathrm{ppm}$ and nitrogen of $80 \mathrm{Kg} \mathrm{N} / \mathrm{fed}^{-1}$ gave the highest total chlorophyll content in onion plant leaves in the two growing seasons.

\section{B. Yield}

\section{Biological yield}

Data in Table (4) reveal a significant increment in biological yield in response to boron foliar application during the two seasons of the study. The increment continued up to $2.4 \mathrm{ppm}$ boron rate, which reached $2.50 \mathrm{Kg} / \mathrm{m}^{2}$ (average of the two seasons), then started to decline at higher boron application rates (3.2 and $4.0 \mathrm{ppm})$. The lower boron levels are more effective than the higher levels in increasing biological yield, as shown in Table (4).
The highest biological yield was obtained in the case of using the highest rate of nitrogen level, (80 $\mathrm{kg} \mathrm{N} / \mathrm{fed}^{-1}$ ). The effect of the interaction of boron at $2.4 \mathrm{ppm}$ with nitrogen rate at $\left(80 \mathrm{~kg} \mathrm{~N} / \mathrm{fed}^{-1}\right)$ was also significant whereas, the highest biological yield was $2.67 \mathrm{Kg} / \mathrm{m}^{2}$ (Average of the two seasons).

\section{Economical yield}

Data in Table (5) reveal that the maximum significant increase in economical yield was observed at $2.4 \mathrm{ppm}$ boron application rate which recorded economical yield of $\left(2.11 \mathrm{Kg} / \mathrm{m}^{2}\right)$ in the two growing seasons. The results are in agreement with those of Manna and Maity ( 2016) [13] who observed that boron foliar application at $0.5 \%$ significantly increased yield of onion. The effect of boron on increasing yield may be due to the improvement of plant growth and the increase of the photosynthates accumulation in the bulbs. 
EFFECT OF BORON AND NITROGEN...

Table (5): Effect of boron and nitrogen fertilizer on economical yield of onion $\left(\mathrm{Kg} / \mathrm{m}^{2}\right)$ during the two growing seasons of 2016/2017 and 2017/2018

\begin{tabular}{|c|c|c|c|c|c|c|c|c|}
\hline \multirow{3}{*}{ Boron conc. Ppm } & \multicolumn{8}{|c|}{ Nitrogen rates kg N/fed. ${ }^{-1}$} \\
\hline & \multicolumn{3}{|c|}{ 2016/2017 } & \multirow{2}{*}{ Average } & \multicolumn{3}{|c|}{$2017 / 2018$} & \multirow{2}{*}{ Average } \\
\hline & 40 & 60 & 80 & & 40 & 60 & 80 & \\
\hline Control & 1.590 & 1.740 & 2.037 & 1.789 & 1.507 & 1.687 & 1.973 & 1.722 \\
\hline 0.8 & 1.683 & 1.867 & 2.153 & 1.901 & 1.617 & 1.810 & 2.083 & 1.837 \\
\hline 1.6 & 1.770 & 2.123 & 2.217 & 2.037 & 1.740 & 2.050 & 2.140 & 1.977 \\
\hline 2.4 & 1.960 & 2.173 & 2.297 & 2.143 & 1.900 & 2.100 & 2.233 & 2.078 \\
\hline 3.2 & 1.493 & 1.480 & 1.497 & 1.490 & 1.447 & 1.463 & 1.500 & 1.470 \\
\hline 4.0 & 1.440 & 1.503 & 1.530 & 1.491 & 1.383 & 1.457 & 1.457 & 1.432 \\
\hline Average & 1.656 & 1.814 & 1.955 & & 1.599 & 1.761 & 1.898 & \\
\hline \multicolumn{9}{|l|}{ L.S.D. at 0.05 for: } \\
\hline Nitrogen & & 0.030 & & & & 0.021 & & \\
\hline Boron & & 0.043 & & & & 0.030 & & \\
\hline Nitrogen $\times$ Boron & & 0.074 & & & & 0.052 & & \\
\hline
\end{tabular}

Table (6): Effect of boron and nitrogen fertilizer on nitrogen content of onion (\%) during the two growing seasons of 2016/2017 and 2017/2018

\begin{tabular}{|c|c|c|c|c|c|c|c|c|}
\hline \multirow{3}{*}{ Boron conc. ppm } & \multicolumn{8}{|c|}{ Nitrogen rates kg N/fed. ${ }^{-1}$} \\
\hline & \multicolumn{3}{|c|}{$2016 / 2017$} & \multirow{2}{*}{ Average } & \multicolumn{3}{|c|}{$2017 / 2018$} & \multirow{2}{*}{ Average } \\
\hline & 40 & 60 & 80 & & 40 & 60 & 80 & \\
\hline Control & 2.493 & 2.747 & 2.990 & 2.743 & 2.553 & 2.810 & 3.063 & 2.809 \\
\hline 0.8 & 2.817 & 2.933 & 2.183 & 2.978 & 2.883 & 2.997 & 3.260 & 3.047 \\
\hline 1.6 & 2.840 & 2.977 & 2.293 & 3.037 & 2.910 & 3.43 & 3.380 & 3.111 \\
\hline 2.4 & 2.883 & 3.070 & 3.343 & 3.099 & 2.953 & 3.123 & 3.450 & 3.175 \\
\hline 3.2 & 2.263 & 2.403 & 2.420 & 2.362 & 2.417 & 2.470 & 2.477 & 2.455 \\
\hline 4.0 & 2.210 & 2.313 & 2.363 & 2.296 & 2.257 & 2.357 & 2.410 & 2.341 \\
\hline Average & 2.584 & 2.741 & 2.932 & & 2.662 & 2.800 & 3.007 & \\
\hline \multicolumn{9}{|l|}{ L.S.D. at 0.05 for: } \\
\hline Nitrogen & & & 0.043 & & & 0.037 & & \\
\hline Boron & & & 0.061 & & & 0.052 & & \\
\hline Nitrogen $\times$ Boron & & & 0.105 & & & 0.091 & & \\
\hline
\end{tabular}

The nitrogen fertilizer applied at $80 \mathrm{Kg} \mathrm{N} / \mathrm{fed}^{-1}$ resulted in the highest of economical yield of (1.93 $\mathrm{Kg} / \mathrm{m}^{2}$ average of the two growing seasons). The effect of the interaction of boron at $2.4 \mathrm{ppm}$ with nitrogen rate of $80 \mathrm{~kg} \mathrm{~N} / \mathrm{fed}^{-1}$ was found to be the best treatment as it gave the highest economical yield of $2.27 \mathrm{Kg} / \mathrm{m}^{2}$, (average of the two growing seasons).

\section{Chemical characteristics}

\section{Nitrogen content in bulb}

Data in Table (6) show a significant increase in the nitrogen content as a result of boron foliar application. The increase continued up to $2.4 \mathrm{ppm}$ boron rate followed by a reduction in the nitrogen content values as boron application level increased. The increase in the nitrogen content by boron application may be due to the role of boron in nitrogen metabolism [14].

Nitrogen fertilizer significantly increased nitrogen content in bulb. The highest nitrogen content in bulb was observed in the case of using the highest rate of nitrogen level. The effect of the interaction between boron and nitrogen treatment showed that boron at $2.4 \mathrm{ppm}$ when interacted with nitrogen at $80 \mathrm{Kg} \mathrm{N} / \mathrm{fed}^{-1}$ gave the highest nitrogen content in bulb.

\section{Potassium content in bulb}

Results in Table (7) indicate that potassium percentages in bulb significantly increased as the boron application rate increased. Bulb potassium concentrations (average of the two seasons) are $2.70,3.57,3.61,3.68,3.72$ and $3.73 \%$ for 0.00 , $0.8,1.6,2.4,3.2$ and $4.00 \mathrm{ppm}$ boron application rate respectively.

As for nitrogen fertilization it could be noticed that there was significant increase in potassium percentages in onion bulbs, whereas increasing nitrogen level from 40 to $80 \mathrm{Kg} \mathrm{N} / \mathrm{fed}^{-1}{ }^{1}$ resulted in increasing potassium percentages in bulb.

The effect of the interaction between boron and nitrogen showed that the highest potassium 
percentages were obtained with $4.0 \mathrm{ppm}$ boron interacted with $80 \mathrm{Kg} \mathrm{N} / \mathrm{fed}^{-1}$ combination in the two growing seasons.

\section{Boron content in bulb}

Results in Table (8) show that boron foliar application caused a significant increase in the bulb boron content. Bulb boron concentration has increased as the boron application rate increased. Bulb boron concentrations (average of the two growing seasons) are 26.63, 31.21, 33.53, 35.47, 39.18 and $40.24 \mathrm{ppm}$ for $0.00,0.8,1.6,2.4,3.2$ and $4.00 \mathrm{ppm}$ boron application rate respectively.

The highest boron concentration in bulb was obtained in the case of using the highest rate of nitrogen level. The interaction effect between boron and nitrogen application showed that the highest boron contents ( $40.74 \mathrm{ppm}$ average of the two growing seasons) were observed from plants received boron at $4.00 \mathrm{ppm}$ with nitrogen at $80 \mathrm{Kg}$ N/fed. ${ }^{-1}$.

\section{d. Nitrogen Utilized}

The obtained results in Table (9) indicated that the highest nitrogen utilized percentage $(37.00 \%)$ (Average of the two growing seasons) was observed in the case of using $2.4 \mathrm{ppm}$ boron. The increase continued up to $2.4 \mathrm{ppm}$ boron rate, then started to decline at higher boron application rates (3.2 and $4.0 \mathrm{ppm})$. The results are in agreement with those findings of Miley et. al [15] who reported that boron enhance the utilization of nitrogen in cotton by increasing the translocation of nitrogen compounds into the boll. The nitrogen utilized percentage was significantly increased with increasing nitrogen level up to $80 \mathrm{Kg} / \mathrm{fed}^{-1}$ in both seasons which gave the highest increase of 27.75 and $27.35 \%$ in the first and the second growing seasons respectively.

The effect of the interaction between boron and nitrogen showed that the greatest nitrogen utilized percentages were 38.25 and $37.68 \%$ produced

Table (7): Effect of boron and nitrogen fertilizer on potassium content of onion (\%) during the two growing seasons of 2016/2017 and 2017/2018

\begin{tabular}{|c|c|c|c|c|c|c|c|c|}
\hline \multirow{3}{*}{ Boron conc. Ppm } & \multicolumn{8}{|c|}{ Nitrogen rates kg N/fed ${ }^{-1}$} \\
\hline & \multicolumn{3}{|c|}{$2016 / 2017$} & \multirow{2}{*}{ Average } & \multicolumn{3}{|c|}{$2017 / 2018$} & \multirow{2}{*}{ Average } \\
\hline & 40 & 60 & 80 & & 40 & 60 & 80 & \\
\hline Control & 2.735 & 2.771 & 2.788 & 2.765 & 2.618 & 2.653 & 2.659 & 2.643 \\
\hline 0.8 & 3.615 & 3.651 & 3.662 & 3.643 & 3.482 & 3.497 & 3.505 & 3.495 \\
\hline 1.6 & 3.686 & 3.692 & 3.701 & 3.693 & 3.528 & 3.534 & 3.543 & 3.535 \\
\hline 2.4 & 3.722 & 3.758 & 3.794 & 3.758 & 3.562 & 3.598 & 2.632 & 3.597 \\
\hline 3.2 & 3.791 & 3.803 & 3.815 & 3.803 & 3.629 & 3.641 & 3.653 & 3.641 \\
\hline 4.0 & 3.806 & 3.813 & 3.822 & 3.814 & 3.645 & 3.650 & 3.659 & 3.651 \\
\hline Average & 3.559 & 3.582 & 3.597 & & 3.411 & 3.429 & 3.430 & \\
\hline \multicolumn{9}{|l|}{ L.S.D. at 0.05 for: } \\
\hline Nitrogen & & 0.030 & & & & 0.129 & & \\
\hline Boron & & 0.043 & & & & 0.182 & & \\
\hline Nitrogen $\times$ Boron & & 0.74 & & & & 0.315 & & \\
\hline
\end{tabular}

Table (8): Effect of Boron and nitrogen fertilizer on boron content of onion (ppm) during the two growing seasons of 2016/2017 and 2017/2018

\begin{tabular}{|c|c|c|c|c|c|c|c|c|}
\hline \multirow{3}{*}{ Boron conc. Ppm } & \multicolumn{8}{|c|}{ Nitrogen rates kg N/fed. $^{-1}$} \\
\hline & \multicolumn{3}{|c|}{$2016 / 2017$} & \multirow{2}{*}{ Average } & \multicolumn{3}{|c|}{$2017 / 2018$} & \multirow{2}{*}{ Average } \\
\hline & 40 & 60 & 80 & & 40 & 60 & 80 & \\
\hline Control & 26.63 & 25.83 & 26.41 & 26.29 & 27.33 & 26.50 & 27.09 & 26.97 \\
\hline 0.8 & 30.43 & 30.34 & 31.21 & 30.76 & 31.23 & 31.43 & 32.03 & 31.65 \\
\hline 1.6 & 32.62 & 33.24 & 33.43 & 33.10 & 33.45 & 34.16 & 34.29 & 33.97 \\
\hline 2.4 & 34.85 & 35.00 & 35.22 & 35.02 & 35.74 & 35.91 & 36.10 & 35.92 \\
\hline 3.2 & 38.42 & 38.61 & 39.33 & 38.79 & 39.43 & 38.95 & 40.34 & 39.57 \\
\hline 4.0 & 39.21 & 39.73 & 40.21 & 39.72 & 40.24 & 40.76 & 41.27 & 40.75 \\
\hline Average & 33.69 & 33.84 & 34.30 & & 34.57 & 34.62 & 35.19 & \\
\hline \multicolumn{9}{|l|}{ L.S.D. at 0.05 for: } \\
\hline Nitrogen & & 0.021 & & & & 0.666 & & \\
\hline Boron & & 0.030 & & & & 0.942 & & \\
\hline Nitrogen $\times$ Boron & & 0.052 & & & & 1.630 & & \\
\hline
\end{tabular}


EFFECT OF BORON AND NITROGEN...

Table (9): Effect of boron and nitrogen fertilizer on $\mathrm{N}$-utilized $(\%)$ by onion plants during the two growing seasons of 2016/2017 and 2017/2018

\begin{tabular}{|c|c|c|c|c|c|c|c|c|}
\hline \multirow{3}{*}{ Boron conc. Ppm } & \multicolumn{8}{|c|}{ Nitrogen rates kg N/fed. ${ }^{-1}$} \\
\hline & \multicolumn{3}{|c|}{$2016 / 2017$} & \multirow{2}{*}{ Average } & \multicolumn{3}{|c|}{$2017 / 2018$} & \multirow{2}{*}{ Average } \\
\hline & 40 & 60 & 80 & & 40 & 60 & 80 & \\
\hline Control & 19.21 & 21.02 & 23.44 & 21.22 & 18.93 & 20.71 & 23.10 & 20.91 \\
\hline 0.8 & 27.93 & 29.62 & 31.61 & 29.72 & 27.51 & 29.19 & 31.14 & 29.28 \\
\hline 1.6 & 30.09 & 33.54 & 34.71 & 32.78 & 29.65 & 33.03 & 34.20 & 32.30 \\
\hline 2.4 & 35.62 & 37.48 & 38.25 & 37.11 & 36.06 & 36.92 & 37.68 & 36.89 \\
\hline 3.2 & 18.03 & 19.41 & 19.80 & 19.08 & 17.76 & 19.17 & 19.55 & 18.83 \\
\hline 4.0 & 17.91 & 18.33 & 18.70 & 18.31 & 17.65 & 18.05 & 18.42 & 18.04 \\
\hline Average & 24.80 & 26.57 & 27.75 & & 24.59 & 26.18 & 27.35 & \\
\hline \multicolumn{9}{|l|}{ L.S.D. at 0.05 for: } \\
\hline Nitrogen & & 0.021 & & & & 0.274 & & \\
\hline Boron & & 0.030 & & & & 0.387 & & \\
\hline Nitrogen $\times$ Boron & & 0.052 & & & & 0.670 & & \\
\hline
\end{tabular}

from the application of $2.4 \mathrm{ppm}$ boron with $80 \mathrm{Kg}$ $\mathrm{N} / \mathrm{fed}^{-1}$ in the first and the second seasons respectively. On the other hand, the lowest one was 17.91 and $17.65 \%$ respectively obtained from applied boron at $4.0 \mathrm{ppm}$ when interacted with nitrogen at $40 \mathrm{Kg} \mathrm{N} / \mathrm{fed}^{-1}$ whereas, nitrogen utilized percentage was decreased by increasing boron rate to $4.0 \mathrm{ppm}$ with increased or decreased nitrogen level.

\section{Conclusion}

It can be concluded that the boron foliar application at $2.4 \mathrm{ppm}$ significantly increased the fresh and dry weights and yield of onion plant as well as the total chlorophyll content, nitrogen utilized of onion. The effect of the interaction between boron and nitrogen indicated that boron at $2.4 \mathrm{ppm}+$ nitrogen at $80 \mathrm{Kg} / \mathrm{fed}^{-1}$ had a significant influence on all traits of the plant subject of this study in both seasons.

\section{References}

1. Hanen, N., Fattouch, S., Annar E. and Neffati M. (2006) Allium Species, Ancient Health Food for the Future In: B. Valdez (ed.). Scientific, Health and Social Aspects of the Food Industry. Europe: In Tech Publisher, pp: 343-354

2. Sampath Kumar, K. P., Bhowmik, D., Jib, C., Jit, B. and Tiwari, P. (2010) Allium Cepa: A Traditional Medicinal Herb and Its Health Benefits, J. Chem. Res., 2(1):283-291.
3. Lee-Jongatae, Ha-Injong, Iee-Changung, Moon-Jinseong and Cho-Yongcho. (2003) Effect of $\mathrm{N}, \mathrm{P}_{2} \mathrm{O}_{5}$ and $\mathrm{K}_{2} \mathrm{O}$ Application Rates and Top Dressing Time on Growth and Yield of Onion (Allium cepa L.) under Spring Culture in Low Land, Korean J. of Horticultural Sci. and Technology, 21(4), 260266.

4. Marschner, H. (1995). Mineral Nutrition of Higher Plants, $2^{\text {nd }}$ edition. Academic Press, London, UK.

5. Amin, P.S. and Shahsavar, A.R. (2012) The Influence of Urea, Boric Acid and Zinc Sulphate on Vegetative Traits of Olive, J. Biol. Environ. Sci., 6(16), 109-113.

6. Maurya, A. N. and Lai, S. (1975b) Boron in Relation to the Growth and Development of Onion (Allium cepa L.), Bangladesh Hort., 3(1), 1-7.

7. Jones, J. B., Wolf, B. and Mills, H. A. (1991) Plant Analysis Handbook. Micro-Macro Publishing, Inc.

8. Johnson, G. V. and Fixen, P. E. (1990) Testing Soils for Sulfur, Boron, Molybdenum and Chlorine. In: Soil Testing and Plant Analysis. $3^{\text {rd }}$ Edition, R.L. Westerman (ed.). SSSA Book Series 3, Soil Science Society of America, Inc. Madison, Wisconsin, USA, pp. 265-273.

9. Buresh, R. J., Austin, E. R. and Craswell, E. T. (1982) Analytical Methods in ${ }^{15} \mathrm{~N}$ Research, Fert. Res., 3, 37-62.

10. Snedecor, G. W. and Cochran, W. G. (1980) Statistical Methods, Seven Ed., Iowa State Univ. Press, Ames., Iowa USA.

11. Snedecor G. W. and Cochran W. G. (1987) Statistical Methods, Six Ed., Iowa State Univ. Press, Ames., Iowa USA. 
12. Paul, J. K., Halder, B. C. and Khan, M. A. (2007) Effects of Boron and Sulphur on the Growth and Yield of Onion, J. Sci. technol. (Dinajpur), 5, 60-66.

13. Manna, D. and Maity, T. K. (2016) Growth Yield and Bulb Quality of Onion (Allium cepa L.) in Response to Foliar Application of Boron and Zinc, Journal of plant nutrition, 39(3), 438-441.
14. Nason, A. and McElory, W. D. (1963) Modes of Action of the Essential Mineral Elements. In:Plant Physiology, F.C. Sreward (ed). Academic press, New york, USA.

15. Miley, W. N., Hardy, G. W. and Sturgis, M. B. (1969) Influence of Boron, Nitrogen and Potassium on Yield, Nutrient Uptake and Abnormalities of Cotton, Agron. J., 61, 9-13. 